\title{
Simulation of Manganese Transport in Groundwater Using Visual MODFLOW: a Case Study from Xiangtan Manganese Ore Area in Central China
}

\author{
Wenchao Xie ${ }^{1,2}$, Bozhi Ren ${ }^{1,2 *}$, Andrew S. Hursthouse ${ }^{1,3}$, Zhenghua Wang ${ }^{1,2}$, Xin Luo ${ }^{1,2}$ \\ ${ }^{1}$ Hunan Provincial Key Laboratory of Shale Gas Resource Exploitation, Xiangtan, 411201, China \\ ${ }^{2}$ School of Civil Engineering, Hunan University of Science and Technology, Xiangtan, 411201, China \\ ${ }^{3}$ School of Computing, Engineering \& Physical Sciences, University of the West of Scotland, Paisley PA1 2BE, UK
}

Received: 25 February 2020

Accepted: 27 July 2020

\begin{abstract}
The release of metals from a mine tailings pond to groundwater is an important pathway to assess the environmental impact of mining residues and implications for wider environmental risk. We research the impact of manganese ore area in Heling Town, Xiangtan City, Hunan Province, central China. The focus is to assess the migration of manganese (Mn) using the Visual MODFLOW model of groundwater flow and the MT3DMS software platform to model solute transport. The modelling objective focuses on evaluating the migration of the pollution plume of manganese over a 20 year time period. The results show the sustained release and transport of $\mathrm{Mn}$ from the tailing pond. The concentration of $\mathrm{Mn}$ in the central pollution halo is $1.97 \mathrm{mg} / \mathrm{L}$, and the maximum detectable range is at $2291 \mathrm{~m}$, with the concentration range exceeding the third level of national groundwater standard is $1280 \mathrm{~m}$. The result provides a basis for the development and utilization of the mining area and the pollution prediction and protection of the tailings pond.
\end{abstract}

Keywords: numerical simulation, visual MODFLOW, solute transport, manganese tailings pond

\section{Intorduction}

Since 2010, Chinese manganese ore import has exceeded 11 million tons, and reached 22 million tons in 2017. China has become the largest importer and consumer of manganese ore. China has a huge demand for manganese ore, but the domestic reserves

*e-mail: bozhiren@126.com of manganese ore are only one third of that of South Africa, which is rich in manganese ore resources. In addition, the grade of manganese ore mined in China is generally low, and the scale of manganese deposits is mainly small and medium-sized, which results in the scattered distribution of mining areas and the difficulty in mining and beneficiation management. In this case, the disordered over mining of manganese ore resources in early China led to the further reduction of manganese ore with low grade, and the serious 
environmental problems around the mining area due to the lack of scientific management, there are huge hidden dangers. Although manganese is one of the trace elements are needed by human body and takes part in many enzymatic processes the human body, long-term excessive intake of manganese may lead to Parkinson's disease, pneumonia, bronchitis [1], and reproductive and immune dysfunction [2-4]. The tailings pond is formed from the solid waste accumulated during the long-term mining, beneficiation and smelting of ore deposits. Under the combined action of rainfall scouring and leaching, the heavy metal elements in tailings have various physical and chemical reactions, such as diffusion, dispersion, desorption and dissociation, forming the pollution source of tailings pond [5]. This material, driven by surface runoff migrates into the subsurface $[6,7]$ and enters the water environment of the surrounding areas leading to wider potential exposure and risk to human health and economic development [8-10].

There is a lot of current interest in the wider environmental impact of residues from mineral exploitation, in particular the large extensively worked deposits in China where exposure levels and spatial extent are potentially very significant [11-14]. To try to mitigate the threat, a number of studies have looked at the wider context to alleviate the threat of tailings to the environment and protect the ecological environment [15-17]. A number of numerical simulation methods have been applied to groundwater systems including FDM (Finite Difference Method), FEM (Finite Element Method), BEM (Boundary Element Method) and FAM (Finite Analytical Method), which have been successful in studying seawater intrusion, land subsidence, reduction of groundwater levels, overexploitation and pollution of groundwater [18 20]. At the same time, with the development of higher ability data processing methods, the Visual MODFLOW programme has been developed by Waterloo Hydrogeologic, Canada, based on the finite difference method basis of the original MODFLOW software combined with modern visualization technology and is widely acknowledged for its powerful visualization features and excellent software support. For example, Khadri et al. established the groundwater flow model of Mahesh River basin in India using MODFLOW software [21]; Xue et al. according to the hydrogeological conditions and remote sensing information, the groundwater numerical model of zhuanlongwan mining area in Mongolia is established [22]; Wang et al. used Visual MODFLOW to study the migration of organic molecules and related nutrients in groundwater of a tailings pond [23]. Morever, Podlase et al. studied the migration of nitrogen compounds in soil water system in the valley agricultural area by establishing groundwater flow model in central Poland [24]. Singh et al. used Visual MODFLOW to evaluate the performance of PRB. The results show that PRB material can effectively reduce the diffusion ability of pollutants in groundwater [25]. At present, numerical simulation is the main means to study groundwater problems, and with the continuous emergence of groundwater problems in the world, it will also promote researchers to explore the methods and applications of numerical simulation.

Our study is based on the manganese ore area of Heling Town, Xiangtan City, central China, with a focus on $\mathrm{Mn}$ in leachate form tailing ponds in the area. Based on the software platform of groundwater flow model Visual MODFLOW and solute transport model MT3DMS, a three dimensional simulation is undertaken to predict the dynamics of Mn release over a 20 year period.

\section{Material and Methods}

\section{Overview of the Study Area}

This study area is located in Heling Town, Yuhu District, Xiangtan city. It is located in subtropical monsoon climate, with an average annual temperature of $17.8^{\circ} \mathrm{C}$ and an average annual precipitation of $1656.6 \mathrm{~mm}$, of which the annual precipitation is concentrated in April and August [26]. The tailing pond is found mainly in a mountainous area, close to residential dwellings with a general slope from high in the northwest and low in the southeast. The total area is about $205 \mathrm{~km}^{2}$, with the highest point at $340 \mathrm{~m}$ above sea level only $35-40 \mathrm{~m}$ from residential dwellings. The aquifer thickness is uneven and the surrounding farmland and small ponds in the area are predominantly supplied by precipitation. The strata in the study area can be mainly divided into hard strata (mainly including phyllitic clay rock, moraine conglomerate, chert rock, clay rock, limestone, etc.) and Quaternary loose sediments (mainly including alluvium, deluvium and eluvium). The groundwater in the area is mainly in the foundation rock and Quaternary sediments. The specific description is as follows:

(1) The underground water in the bedrock includes the fissure water in the Upper Sinian siliceous layer and the pore fissure water in the Permian coarsegrained sandstone. The fissure water in the Upper Sinian siliceous layer is mainly distributed in the north of the Xiannushan anticline. The thickness distribution of the aquifer in the Upper Sinian siliceous layer is uneven, generally 50-100 meters, but there are also more than 100 and less than 50 meters of aquifer thickness. The rock of the aquifer is mainly composed of chert and claystone. The lower part is dominated by claystone, with coarse particles and generally undeveloped fissures; the upper part is a thick layered grouted rock layer, with relatively stable lithology and no change within $1-2 \mathrm{~km}$ along the strike. There are two types of fractures: one is weathering fracture, the other is joint fracture. The upper part is dominated by weathering fractures, and the lower part is dominated 
by layer fractures and joint fractures formed by tectonic action. The depth of weathering fractures can reach 80 meters. Pore fissure water in Permian coarse-grained sandstone is mainly distributed in the northeast of the mining area. According to the field survey data, the particles of sandstone change from fine to coarse from top to bottom. The upper fine-grained sandstone is clay like without water, and the lower coarse-grained sandstone is intensively weathered with full of water. The impermeable fine-grained sandstone weathering layer becomes the water resisting roof of the aquifer in this area, so the water in the coarse-grained sandstone below is confined water.

(2) The groundwater in the Quaternary sediments includes pore water in the old Quaternary loose gravel layer and pore water in the valley loose deposits. The pore water in the old Quaternary loose gravel layer is mainly distributed near Xiangtan City in the southeast of the study area. According to the survey data, the aquifer is 4.45 7.63 meters thick, with an average of 5 6 meters. The lithology is from top to bottom: Clay pebble - pebble with gravel - pebble with gravel. The water bearing gravel layer is buried below the surface of $6 \sim 8$ meters. The roof of the aquifer is impermeable sandy clay or clay with an elevation of $26.60 \sim 30.05$ meters and a thickness of 2.78 3.35 meters. The floor of the aquifer is impermeable Tertiary red sandstone. The pore water in the loose deposits of the valley is mainly distributed in the wide valley bottom, with small area and relatively scattered. The lithology of the loose deposits in the valley bottom is sandy clay, generally with less water, which is a weak permeable layer. The groundwater aquifer in this area has poor water permeability and weak groundwater circulation, so the groundwater pollution is hard to disperse.

The hydrogeological sketch map and section map of the study area are shown in Fig. 1 and Fig. 2 respectively. A series of wells were used as sampling points. There are 8 head observation wells and 3 concentration observation wells on the site. The head value obtained from the head observation wells is used to calibrate the water flow model. And data from the

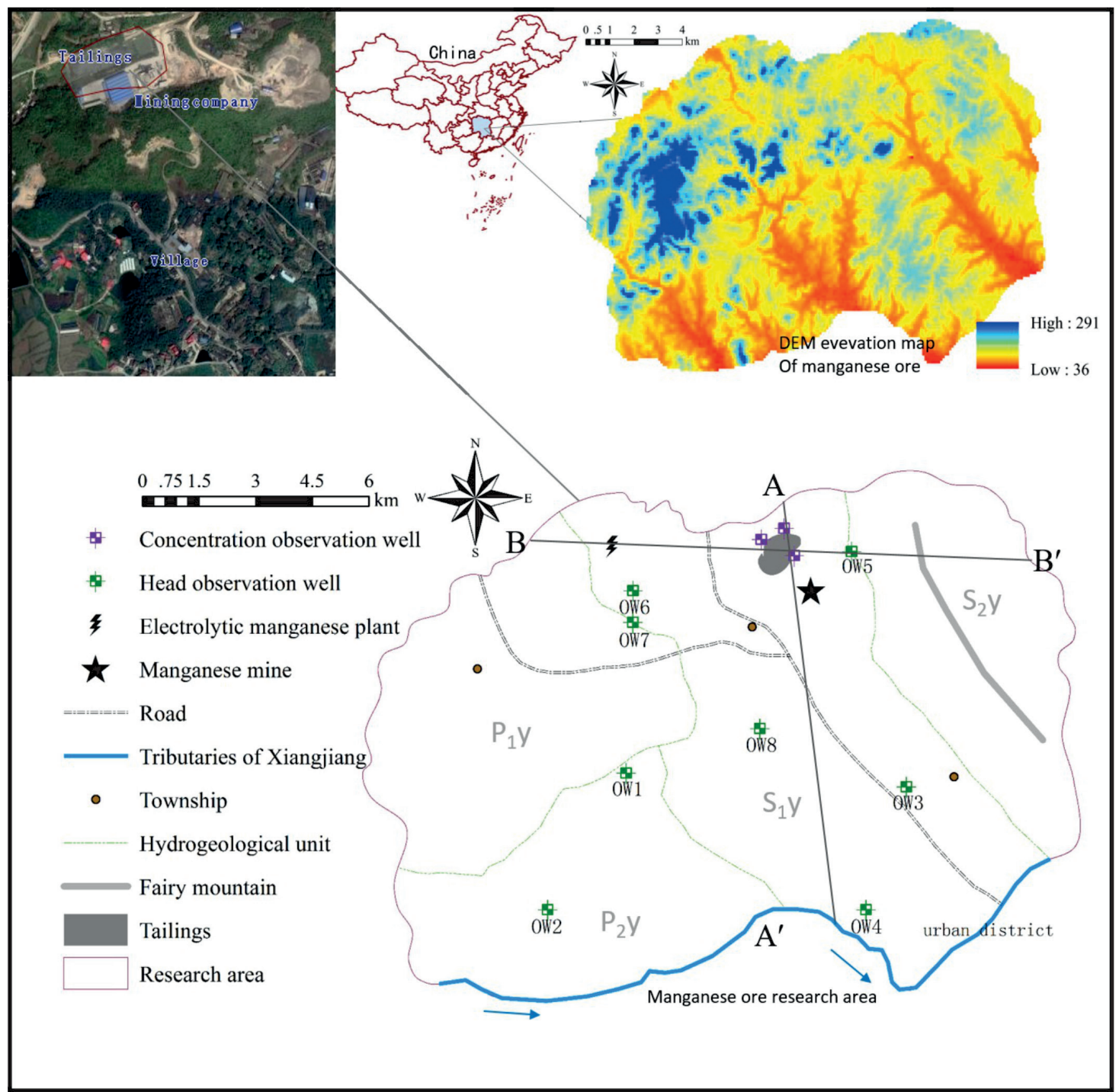

Fig. 1. Geological-hydrogeological map of the study area in the Xiangtan manganese ore of Hunan Province (China). 

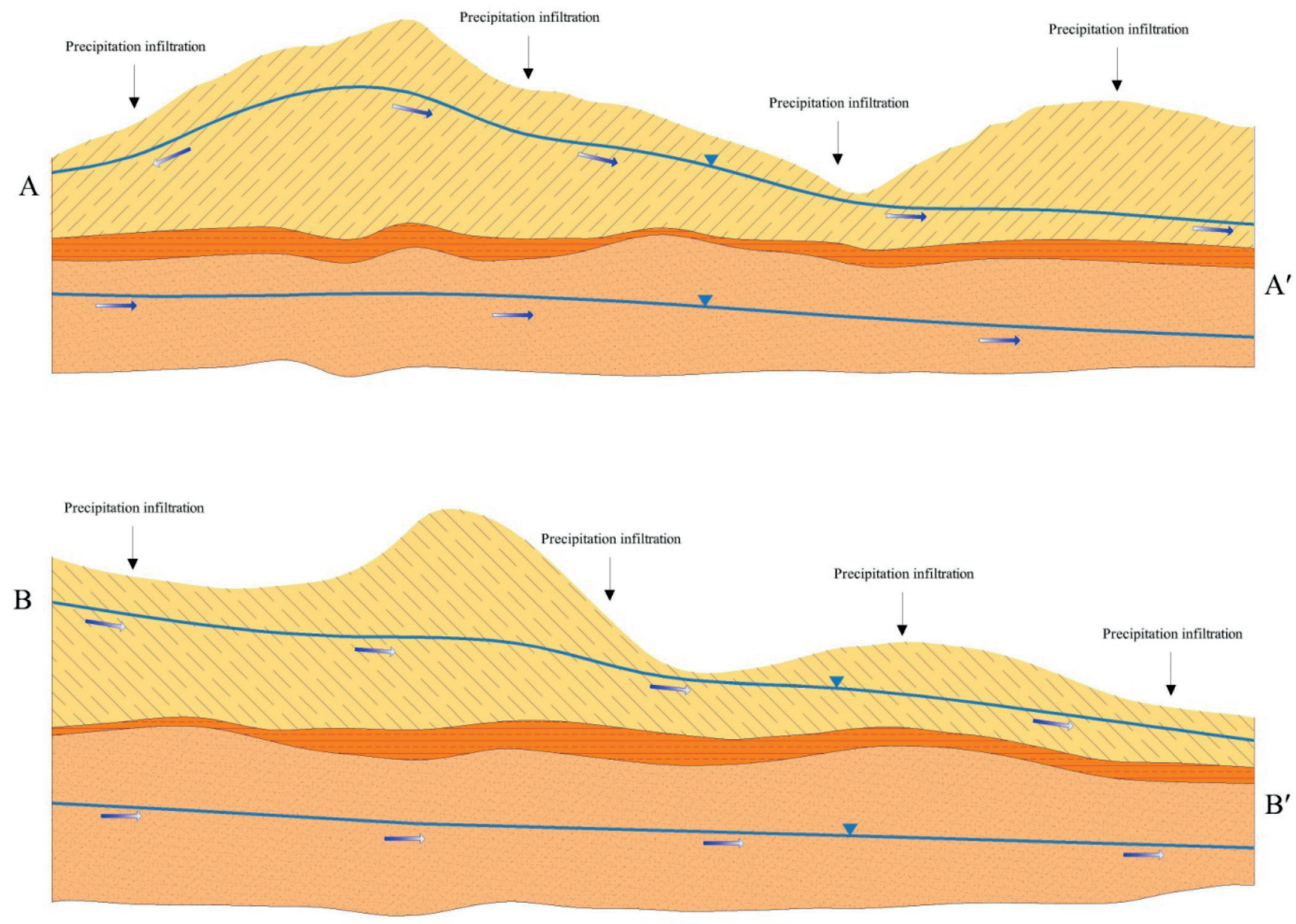

Fig. 2. Cross-sections A-A' and B-B' of the geometrical-structural and aquifer groundwater system in the study area (Fig. 1 shows crosssection locations).

concentration observation wells was used to collect information on $\mathrm{Mn}$ concentration in the groundwater between 2012-2015, which is used to calibrate and adjust the solute transport model.

\section{Mathematical Model}

\section{Mathematical Model of Groundwater Flow}

Groundwater flow varies in different time and space. Therefore, in order to reduce the difficulty of simulation, the groundwater in the study area is defined as steady flow. In addition, due to the variation in geological structure, the hydrogeological parameters are also changed, so the study area is generalized as heterogeneous. The shallow aquifer can be divided into different areas on the basis of numerous different parameters (such as permeability coefficient). Owing to the difficulty of exploration, the relative aquiclude and pressure bearing layer can be generalized into one type of permeability coefficient $[27,28]$. Consequently, the conceptual model of groundwater hydrogeology in tailing area can be generalized as heterogeneous isotropic stable groundwater seepage system. Based on the current situation of the research area, the groundwater seepage model can be generalized as heterogeneous isotropy. And the calculation formula is as follows [27]:

$$
\left\{\begin{array}{c}
\frac{\partial}{\partial x}\left(K \frac{\partial H}{\partial x}\right)+\frac{\partial}{\partial y}\left(K \frac{\partial H}{\partial y}\right)+\frac{\partial}{\partial z}\left(K \frac{\partial H}{\partial z}\right)+W=S_{s} \frac{\partial H}{\partial t}, t>0,(x, y, z) \in \Omega \\
\left.H(x, y, z, t)\right|_{S_{1}}=H_{1}(x, y, z, t),(x, y, z) \in S_{1} \\
\left.H(x, y, z, t)\right|_{t=0}=H_{0}(x, y, z), t \geq 0
\end{array}\right.
$$

Where: $\mathrm{K}$ is the permeability coefficient, in $\mathrm{m} / \mathrm{d} ; \mathrm{H}$ is the water head, in $\mathrm{m}$; W is the water flow in or out of the aquifer from the vertical direction in unit time and volume, with positive inflow and negative outflow; $\mathrm{S}_{\mathrm{S}}$ is the water storage rate, and the total water released from the aquifer in unit volume when the water head is reduced by one unit, in $\mathrm{L}^{-1} ; \mathrm{H}_{0}$ is the initial water level, in $\mathrm{m} ; \mathrm{H}_{1}$ is the first kind of boundary water head, in $\mathrm{m}$. 


\section{Mathematical Model of Pollutant Transport}

Using the MT3DMS module of Visual MODFLOW to simulate the transport route and situation of solute in groundwater can be more intuitively expressed, and its calculation formula is as follows [29]:

$$
n \frac{\partial C}{\partial t}=\frac{\partial}{\partial x_{i}}\left(n D_{i j} \frac{\partial C}{\partial x_{j}}\right)-\frac{\partial}{\partial x_{i}}\left(n v_{i} C\right)-C^{\prime} W
$$

Where: $\mathrm{C}$ is the concentration of pollutants in aquifer, in $\mathrm{mg} / \mathrm{L} ; \mathrm{n}$ is the effective porosity of aquifer; $\mathrm{X}_{\mathrm{i}}$ is the spatial coordinate variable,in $\mathrm{m}$; $\mathrm{t}$ is the time, in day; $\mathrm{C}^{\prime}$ is the concentration of pollutants in source and sink terms, in $\mathrm{mg} / \mathrm{L} ; \mathrm{D}_{\mathrm{ij}}$ is the hydrodynamic dispersion coefficient, $\left(\mathrm{L}^{2} / \mathrm{d}\right) ; \mathrm{W}^{11}$ is the strength of surface source and sink terms, $\mathrm{m}^{3} /\left(\mathrm{d} \cdot \mathrm{m}^{2}\right) ; \mathrm{V}_{\mathrm{i}}$ is the seepage velocity of groundwater $(\mathrm{m} / \mathrm{d})$.

The migration process of pollutants in groundwater is affected by many factors, such as convection, dispersion, adsorption, physical decay, biodegradation, chemical reaction and volatilization. However, due to the hidden characteristics of groundwater, it is difficult to study the migration process of pollutants in groundwater. Due to the main factor of pollutant migration in groundwater is convection dispersion, it will greatly reduce the difficulty and error of this research if only considering the convection dispersion effect of pollutants in groundwater. But the actual range of pollutant diffusion may be slightly smaller than the prediction range of numerical simulation.

Visual MODFLOW, developed by Waterloo Hydrogeologic, Canada, is a numerical simulation software with underground water flow, seepage modeling and visualization processing for solute transport. At present, it has been widely used by hydrogeological researchers in the simulation and prediction of solute transport in underground water flow field. In this study, Visual MODFLOW and MT3DMS were used to calculate the migration of specific and the simulation of the migration under variable density water flow. The WHS calculator with stable solution and fast convergence is selected to solve the groundwater flow equation. The Generalized conjugate gradient (GCG) method and the upstream finite difference (UFD) method are selected to solve the solute transport equation. Compared with the iterative method, this method can set the maximum transport step length, use a relatively short method to calculate the finite difference equation, and also has the advantage of specifying the output time.

\section{Model Establishment and Calculation Analysis}

\section{Model Generalization}

According to the hydrogeological data and field survey, the model of the study area is divided into phreatic water layer, aquiclude and confined layer. The aquifer groundwater in the study area is mainly the groundwater in the bedrock of the higher altitude area, and the groundwater in the bedrock includes the fissure water in the Upper Sinian siliceous layer and the fissure water in the Permian coarse-grained sandstone [30]. The groundwater dynamics in the region is mainly affected by the natural climate. Human factors also play a role which is becoming more and more intense. The atmospheric precipitation in the study area is the main source of groundwater supply, however, the ponds and farmland in the area are rarely connected with groundwater. The aquifer in the south is cut by the tributary of Xiangjiang River. The roof of the aquifer is higher than the water level elevation of the tributary of Xiangjiang River, and the groundwater is mostly discharged from the south. Therefore, the main flow direction of groundwater is from the northern hills to the southern plain area. In addition, groundwater discharge caused by mining and human activities can be generalized as a pumping well.

The boundary conditions of numerical simulation are usually used to express the physical conditions of seepage boundary, that is, the conditions that the head (or seepage flow) should meet on the boundary of seepage area. Precipitation infiltration is the main source in the study area and other supply items are much less significant, so the supply in the area is generalized as precipitation supply. In the northern part of the area, there is basically no flow exchange of groundwater, and the west, North and East are surrounded by mountains, with atmospheric precipitation converging to the south along the terrain. Therefore, the western, northern and eastern boundaries are generalized as zero flux boundaries. The overall terrain of the study area is high in the northwest and low in the southeast. The infiltration of atmospheric precipitation along with the groundwater flow is discharged to the tributary of Xiangjiang River from the north to the south. The cutting aquifer of the tributary of Xiangjiang River in the South can be generalized as a constant head boundary. The bottom of the study area is the bedrock with weak water permeability, which is generalized as the water resistant floor.

\section{Main Parameters of the Model}

In this study, the vertical movement of groundwater system is mainly inter aquifer flow, and only the convection and dispersion of pollutants in groundwater flow are considered.

The main factors affecting the prediction accuracy of the model are hydrogeological parameters and solute transport parameters. At present, in hydrogeological research, these parameters are usually obtained by hydrogeological experiments or by using the empirical values of hydrological survey. The hydrogeological parameters of the study area are preliminarily obtained, according to the hydrogeological conditions survey of 
Table 1. Main hydrogeological conditions in the study area.

\begin{tabular}{|c|c|c|c|c|c|}
\hline \multirow{2}{*}{ Partition name } & Hydraulic conductivity $/\left(\mathrm{m} \cdot \mathrm{d}^{-1}\right)$ & \multirow{2}{*}{$\begin{array}{c}\text { Total } \\
\text { porosity }\end{array}$} & $\mathrm{Sy}$ & $\mathrm{Ss} /(\mathrm{m})$ & \multicolumn{2}{|c|}{$\begin{array}{c}\text { Longitudinal dispersion } \\
\alpha_{\mathrm{L}}\end{array}$} \\
\cline { 1 - 2 } $\mathrm{P}_{1} \mathrm{y}$ & 0.56 & & 0.16 & $1.23 \times 10^{-3}$ & 0.381 \\
\hline $\mathrm{P}_{2} \mathrm{y}$ & 0.67 & & 0.13 & $1.08 \times 10^{-3}$ & 0.343 \\
\hline $\mathrm{S}_{1} \mathrm{y}$ & 1.78 & \multirow{2}{*}{0.3} & 0.14 & $1.16 \times 10^{-3}$ & 0.384 \\
\hline $\mathrm{S}_{2 \mathrm{y}}$ & 0.84 & 0.14 & $1.14 \times 10^{-3}$ & 0.363 \\
\hline Relative aquiclude & $2 \times 10^{-5}$ & 0.12 & $1.07 \times 10^{-3}$ & 0.315 \\
\hline Confined aquifer & 1.5 & & 0.15 & $1.25 \times 10^{-3}$ & 0.333 \\
\hline
\end{tabular}

Xiangtan Manganese ore area in Hunan Province [30], as well as hydrogeological manual (Second Edition) and hydrogeological basis (Sixth Edition). Then, referring to the method proposed by benhachmi et al. [31] the hydrogeological parameters of the model are obtained by adjusting the parameters such as hydraulic conductivity and water storage rate, making the calculated value of water head in the model matches the observed value. After the calibration of groundwater flow model, it is necessary to calibrate the solute transport model. According to the mathematical equation of solute transport, the solute transport is mainly affected by the diffusion coefficient of pollutants and the recharge concentration of pollutants. Similar to the calibration of flow model, the calibration of pollutant transport model is mainly through adjusting the dispersion, until the concentration observation value is consistent with the calculated value of the model [32].

The main hydrogeological parameters of the study area are shown in Table 1. Among them, the hydraulic conductivity of the phreatic layer is divided into four zones, and the aquiclude and the confined layer are respectively generalized into one zone (as shown in Fig. 3). In this simulation, the finite difference method is used to establish the flow model under the Visual MODFLOW software, and the research area is divided into $63 \times 70$ grids.

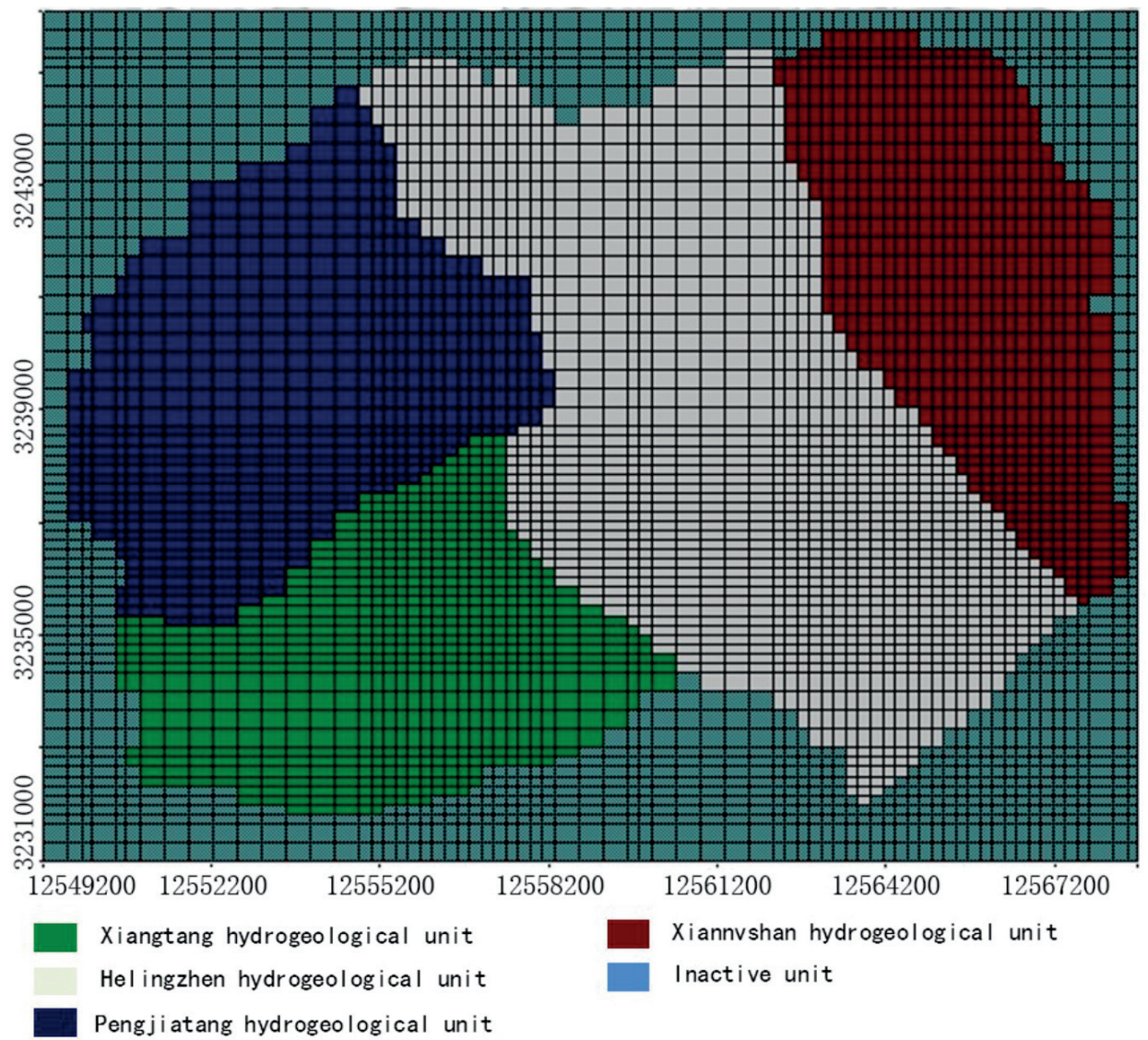

Fig. 3. Division of hydraulic conductivity of aquifer in the study area. 


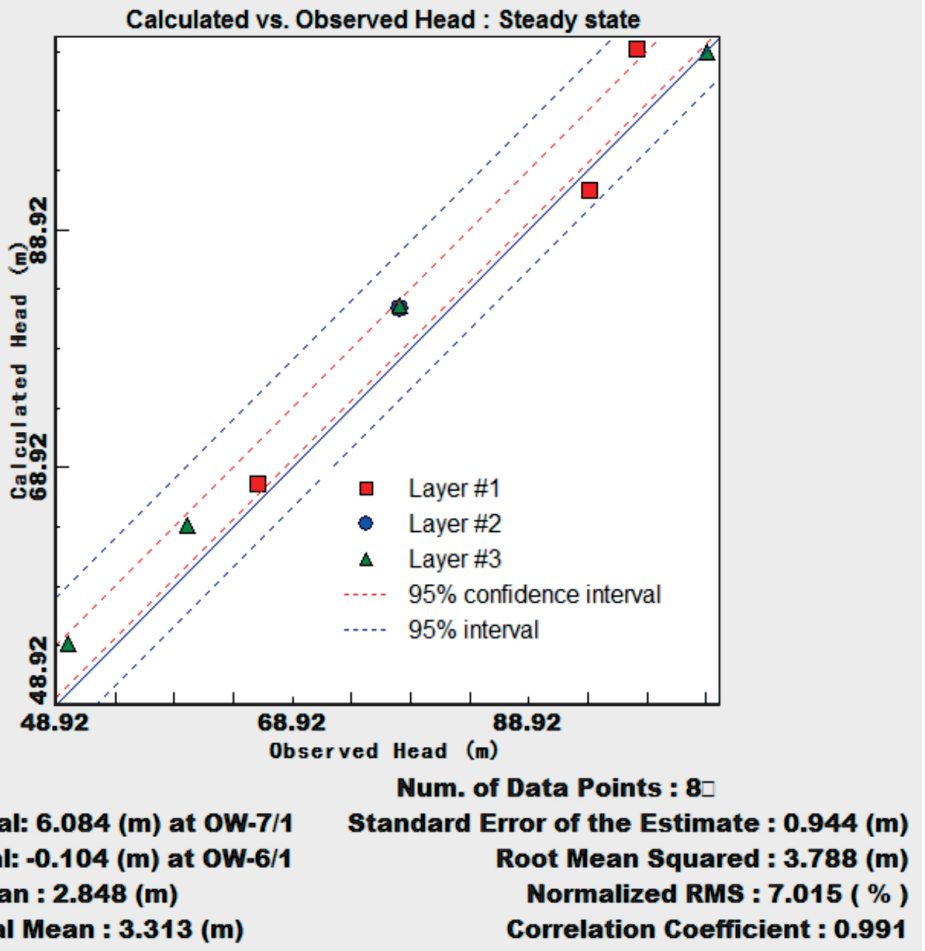

Fig. 4. matching results of monitoring well water level and simulated water level.

\section{Results and Discussion}

\section{Model Calibration and Test}

The calibration and test of the model is an important step in the study of simulation operation. Only after the accurate verification of the model can accurately predict the concentration distribution of pollutants in the future [33]. There are 8 water head observation wells and 3 concentration observation wells in the study area, as shown in Fig. 1. Since the established flow model has been described above as a stable flow model, it is considered that the groundwater level in the study area is stable. Taking the log of the instantaneous water level head observation as the groundwater level of this point for model verification, the results obtained by repeatedly adjusting the parameters are shown in Fig. 2. This shows the difference between the observed value and the calculated value of No. 7 observation well is $6.08 \mathrm{~m}$, which is the maximum value, and the difference between the calculated value and the observed value of No. 6 observation well is $0.1 \mathrm{~m}$, which is the minimum value. The average error of 7 monitoring wells selected in this study is $2.848 \mathrm{~m}$, and the average absolute error is $3.313 \mathrm{~m}$, which meets the basic accuracy requirements for simulation.

Actually, the monitoring data from 2012 to 2015 are used for the observation data in the concentration observation well. Through debugging the parameters in the model to correct the model, and then using the monitoring data in the monitoring well to test the model, judge the reliability of the precision of the model established by studying the consistency of the observed value and the calculated value in the simulation test result (Fig. 4).

Fig. 5 is the fitting curve of three concentration observation wells in the study. Among them, A, B and $\mathrm{C}$ correspond to No. 1, 2 and 3 concentration observation wells respectively. The concentration observation well data in the figure basically conforms to the Visual MODFLOW simulation curve, so the solute migration model can be used to predict the migration concentration for $\mathrm{Mn}$ in groundwater in the future.

\section{Vector of Groundwater Flow and Pathlines of Particle}

The aquifer parameters and boundary conditions are input into the solute model of groundwater, and the simulation results are obtained by using Visual MODFLOW software and running the water flow module, modpath module and MT3DMS module at the same time. Fig. 6 below is the output result of modpath module. It can be seen that the migration path of solute in underground water is from the tailing pond along the vertical direction of water head contour to the South tributary of Xiangjiang River.

\section{SoluteTransport}

Based on the established groundwater flow and solute transport model, the groundwater pollutant manganese is predicted. The simulation time is set as 20 years, the maximum time step is set as 200 days, 
a)

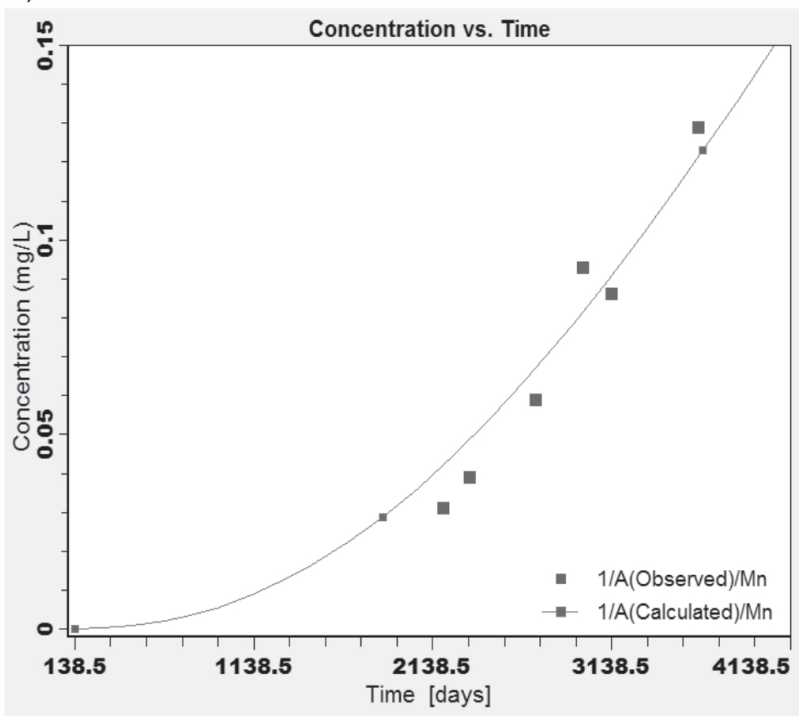

b)

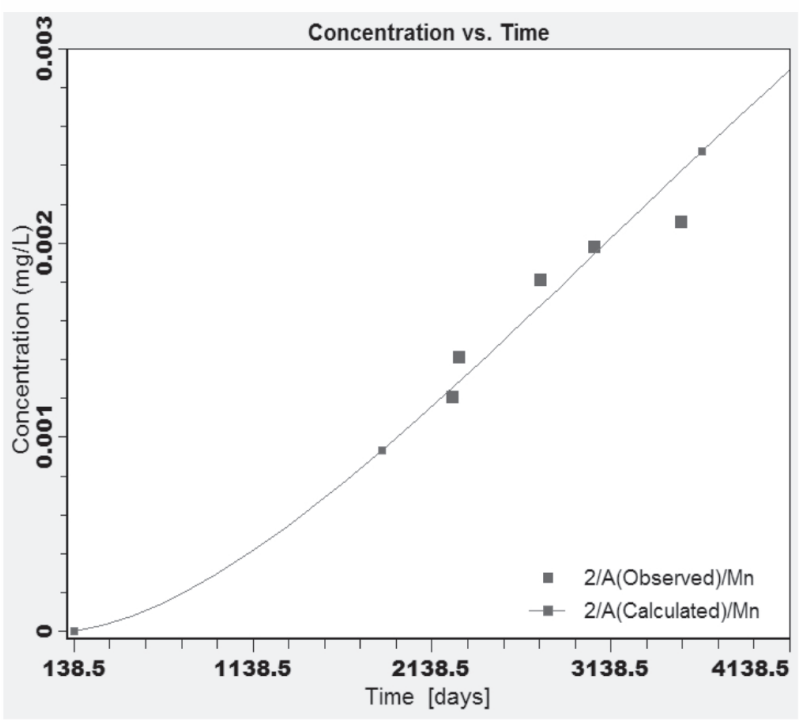

c)

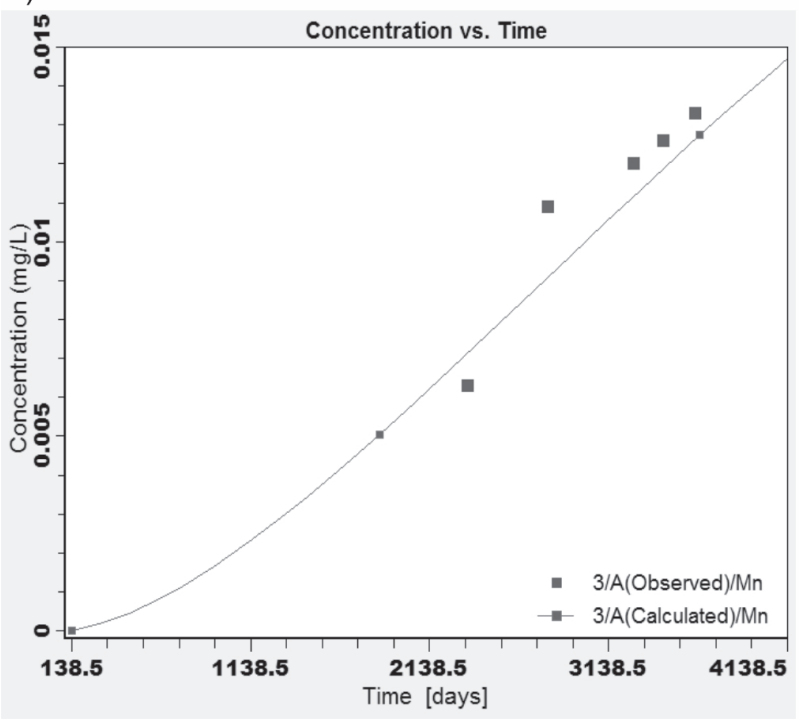

Fig. 5. observed and calculated values of Mn concentration in groundwater. a) No.1 concentration monitoring well, b) No.2 concentration monitoring well, c) No. 3 concentration monitoring well.

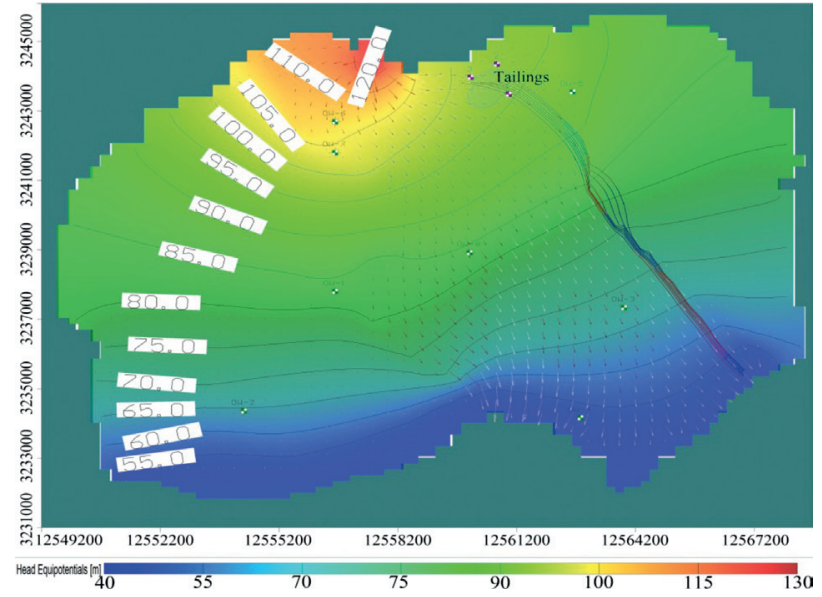

Fig. 6. Trace and vector map of study area.

the multiplier is 1.1 , and the specified output time is 2, $4,8,10,15$ and 20 years respectively. The calculation results of selecting the first layer are shown in Fig. 7, the calculation results of vertical solute migration obtained by taking the east-west direction of the leakage as the profile are shown in Fig. 8, and the maximum solute migration distance of different aquifers with time curve obtained by analyzing the data are shown in Fig. 9.

It can be seen from the figure that the pollution source diffuses in a point form and continuously leaks into the groundwater, causing the groundwater pollution. In this case, it can be inferred that the concentration of $\mathrm{Mn}$ pollutant in the waste enter into the groundwater will increase with the passage of time. And the direction of migration of the pollution plume is basically the same as the flow direction of groundwater, it is elliptical along the flow direction of groundwater. The diffusion range of pollution plume in $0 \sim 8$ years is faster than that in $15 \sim 20$ years. Therefore, with the expansion of the migration range, the diffusion speed of pollution plume is gradually slowing down. In the second year, the concentration of pollutants in the central area of the pollution halo was $0.42 \mathrm{mg} / \mathrm{L}$, for which the maximum detectable range/migration distance is $1110 \mathrm{~m}$, and the longest distance for which the concentration exceed the grade III standard for groundwater is $385 \mathrm{~m}$. In the eighth year of simulation, the concentration of pollutants in the central area of pollution halo is $1.15 \mathrm{mg} / \mathrm{L}$, of which the maximum range of pollution detection is $1612 \mathrm{~m}$, and the longest distance for concentration exceed the grade III standard for groundwater is $822 \mathrm{~m}$. By the $15^{\text {th }}$ year of simulation, the concentration of pollutants in the central area of the pollution halo is $1.71 \mathrm{mg} / \mathrm{L}$, for which the maximum range for detection is $1909 \mathrm{~m}$, and the longest distance for concentration exceed the grade III standard for groundwater is $1182 \mathrm{~m}$. After 20 years of simulation, the concentration of pollutants in the central area of pollution halo is $1.97 \mathrm{mg} / \mathrm{L}$, for which the maximum detectable range/migration distance is $2291 \mathrm{~m}$, 

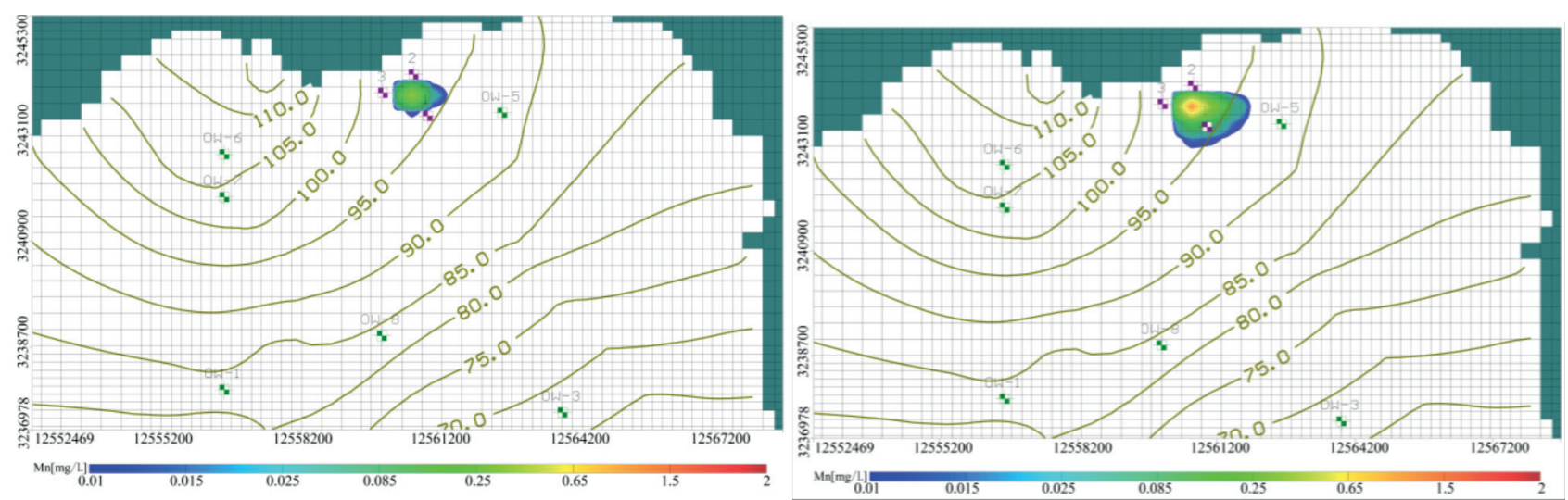

Mn migration in the $2^{\text {nd }}$ year

Mn migration in the $8^{\text {th }}$ year

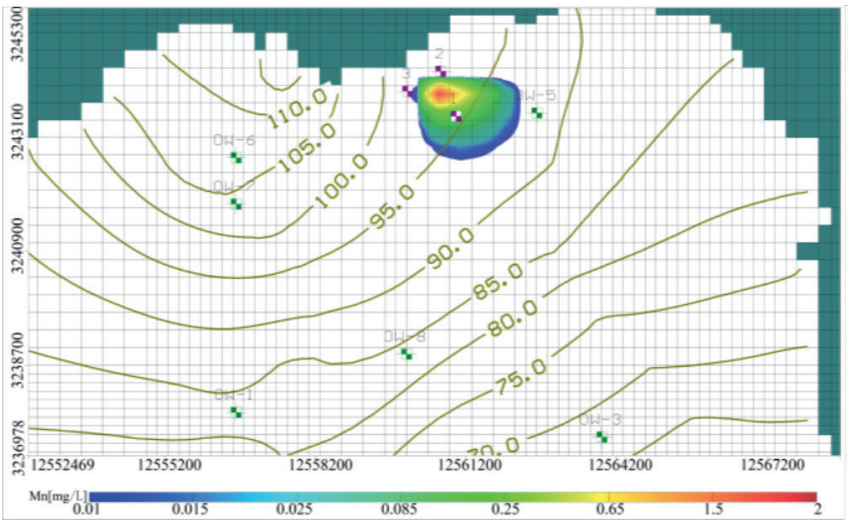

Mn migration in the $15^{\text {th }}$ year

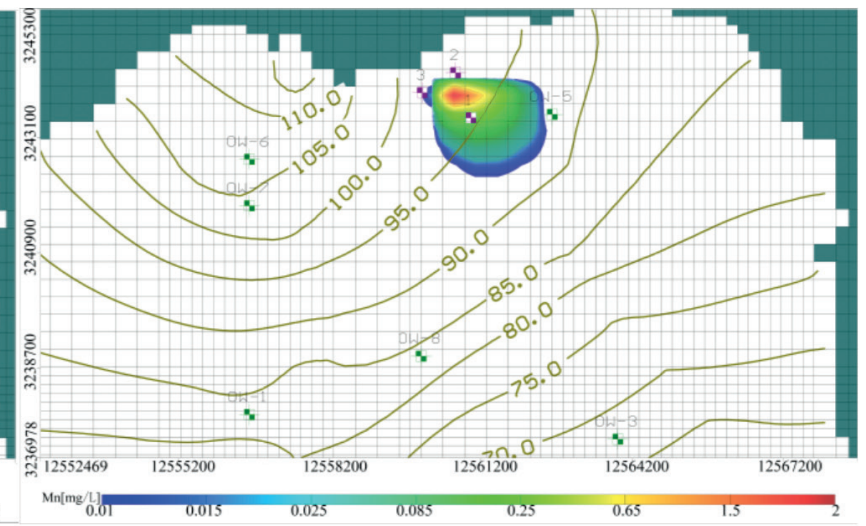

Mn migration in the $20^{\text {th }}$ year

Fig. 7. Prediction of manganese migration in groundwater within 20 years $(0.01 \mathrm{mg} / \mathrm{L}$ is the laboratory detection limit).

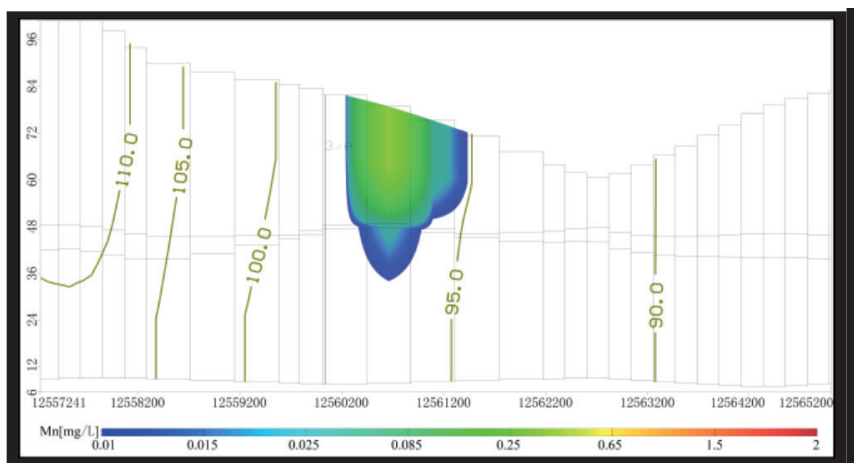

Mn migration in the $2^{\text {nd }}$ year

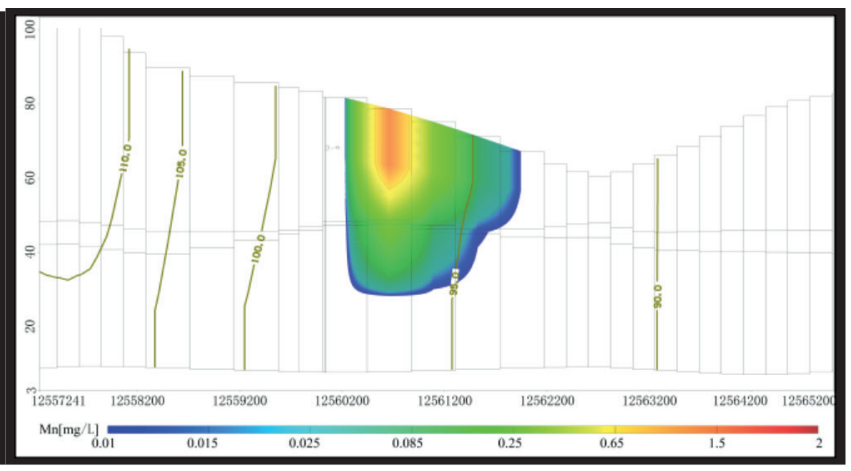

Mn migration in the $8^{\text {th }}$ year

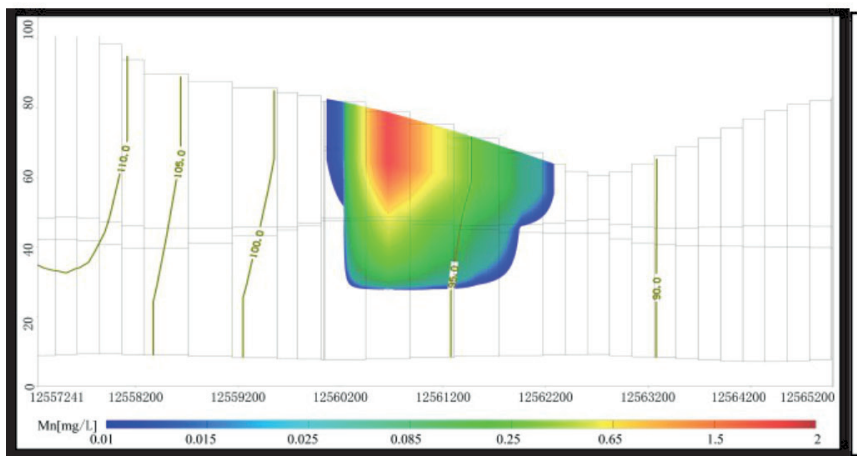

Mn migration in the $15^{\text {th }}$ year

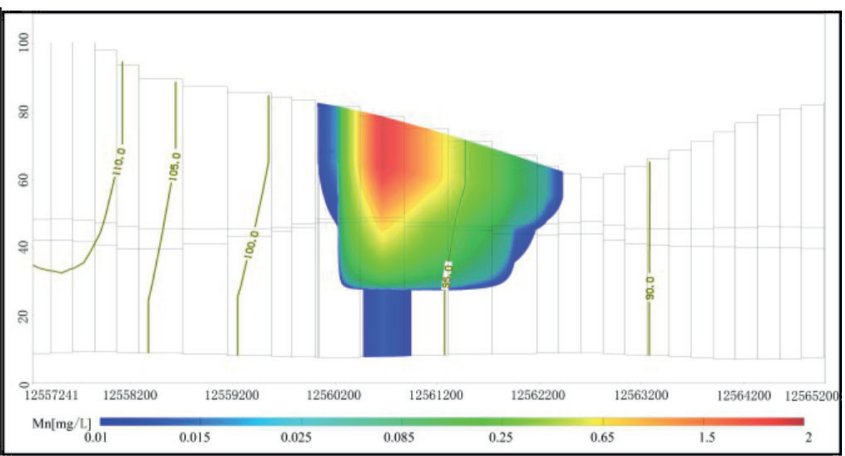

Mn migration in the $20^{\text {th }}$ year

Fig. 8. Prediction of vertical migration of manganese in groundwater system within 20 years $(0.01 \mathrm{mg} / \mathrm{L}$ is the laboratory detection limit). 


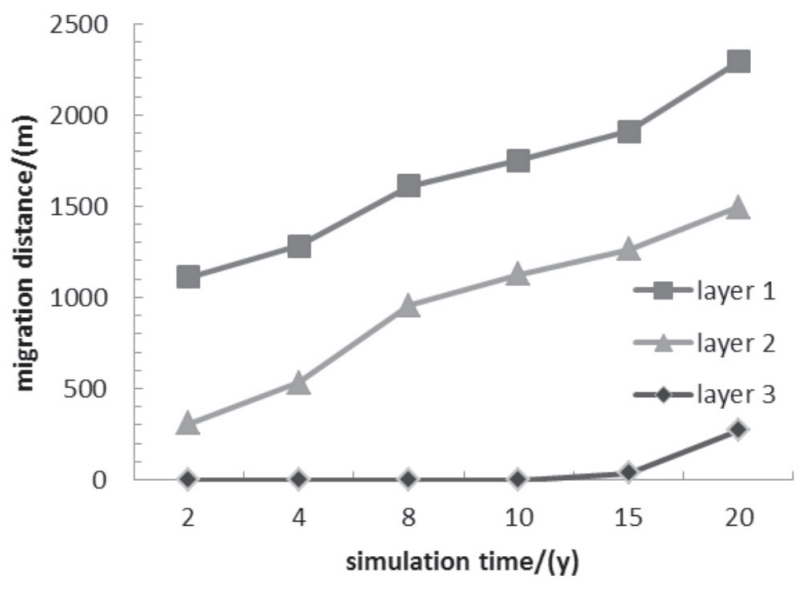

Fig. 9. Broken line of the furthest detectable distance of Mn in groundwater.

and the longest distance for concentration exceed the grade III standard for groundwater is $1280 \mathrm{~m}$. This is the furthest range for pollutant diffusion and shows migration to the southeast along the flow path. It also shows steady migration towards the main Xiangjiang River.

In the vertical direction: it can be seen from the figure that the diffusion speed of pollutants in the first $0 \sim 8$ years is faster than that for the second 15 20 years. Therefore, with the expansion of the migration range, the diffusion speed of pollution plume is gradually slowing down. When the pollution plume spreads to the third layer of the model, the migration speed is again accelerated. When the pollutants migrate to the 20th year, the highest concentration of manganese in the first layer of groundwater reaches $1.8 \mathrm{mg} / \mathrm{L}$, which poses a great threat to human health and ecological environment. In addition, the pollution speed of the third layer is accelerating. If measures are not taken in time, a large area of pollution will be caused to the groundwater system.

Among the measures that can be taken, it should be considered to pave the anti-seepage cushion in the tailings accumulation area to reduce the infiltration of pollutants at first. At present, HDPE anti-seepage membrane is commonly used to treat the tailings pond leakage. In addition, drainage channels should be built around the tailings dump, to avoid the rainwater runoff containing a large amount of pollutants into the surrounding environment under the condition of high intensity precipitation. At the same time, appropriate measures can be taken to purify the polluted groundwater. In a word, the treatment of groundwater pollution in the tailing area should be based on the source treatment, to avoid long-term pollution of groundwater by pollution sources, and timely assess the current situation of groundwater pollution, so as to effectively ensure the safety of drinking water sources for residents.

\section{Uncertainty Analysis}

Due to the special nature of groundwater, uncertainty analysis should be carried out in the numerical simulation of groundwater. There are many factors causing uncertainty, some of which can not be avoided, and some are caused by the limitations of research methods. The following is a description of some uncertain factors generated in this study. In this study, only a preliminary investigation and simulation of manganese in groundwater in Xiangtan manganese ore area has been made. There may be some errors in the actual distribution of manganese in groundwater and hydrogeological conditions. The accuracy of the simulation results is affected by many factors, such as the location of the monitoring well, the monitoring accuracy of the monitoring well and whether the model parameters are appropriate. These uncertainties may cause deviation to the numerical simulation results of the study area, but they do not mean that the simulation results are invalid. Therefore, it needs to be further improved in the future work.

\section{Conclusion}

In this study, the manganese ore area of Heling Town, Xiangtan City, Hunan Province, central China is used to study manganese pollution of groundwater. Based on Visual MODFLOW and MT3DMS software platform, the migration of the pollution plume of $\mathrm{Mn}$ over a 20 year period is predicted. The results are as follows: (1) Visual MODFLOW can directly reflect the change of groundwater quality in space and time. Visualization approach improves the assessment and understanding of complex 3 dimensional data. Establish and calibrate groundwater flow model. The results show that the maximum difference between the observed value of observation well and the calculated value of model is $6.08 \mathrm{~m}$.The average absolute error is $3.313 \mathrm{~m}$ and the overall correlation coefficient is 0.991 , which basically meets the requirements of accuracy for simulation; (2) The transport model for $\mathrm{Mn}$ in groundwater is built in the MT3DMS module of Visual MODFLOW and its reliability is verified. In the $20^{\text {th }}$ year of the simulation, the pollution range reaches the maximum value, and the pollutant concentration in the central area of the pollution halo is $1.97 \mathrm{mg} / \mathrm{L}$, in which the maximum range in the horizontal direction is $2291 \mathrm{~m}$, and the longest distance for concentration exceed the grade III standard for groundwater is $1280 \mathrm{~m}$. In the longitudinal direction, pollutants spread to the confined aquifer and reach the confined layer, and the diffusion speed increases, endangering the deep groundwater.

In this paper, the migration regularity of manganese in groundwater is studied, which provides a direction for solving the problem of groundwater pollution in mining area. In addition, the research method can provide basis 
for groundwater health risk assessment in mining area, and avoid the occurrence of pollution accidents. Finally, the pollution prediction is carried out for the areas with long-term pollution risk, so as to provide help for the long-term sustainable development of groundwater.

\section{Acknowledgements}

This work was supported by the National Natural Science Foundation of China (Nos. 41973078) and the Ministry of Education in China Project of Humanities and Social Science( 2019JJ40081)

\section{Conflict of Interest}

The authors declare no conflict of interest.

\section{References}

1. BOWMAN A.B., KWAKYE G.F., HERRERO HERNÁNDEZ E., ASCHNER M. Role of manganese in neurodegenerative diseases. J. Trace Elem. Med. Biol. 25 (4), 191, 2011.

2. ASCHNER M., ERIKSON K.M., DORMAN D.C. Manganese dosimetry: species differences and implications for neurotoxicity. Crit. Rev. Toxicol. 35 (1), 1, 2005.

3. BARCELOUX D.G., BARCELOUX D. Manganese. J. Toxicol.: Clin. Toxicol. 37 (2), 293, 1999.

4. VARTANIAN J., SALA M., HENRY M., HOBSON S.W., MEYERHANS A. Manganese cations increase the mutation rate of human immunodeficiency virus type $1 \mathrm{ex}$ vivo. J. Gen. Virol. 80, 1983, 1999.

5. ZHANG X., YANG H., CUI Z. Evaluation and analysis of soil migration and distribution characteristics of heavy metals in iron tailings. J. Cleaner Prod. 172, 475, 2018.

6. ZHANG Y., REN B., HURSTHOUSE A., DENG R., HOU B. Leaching and Releasing Characteristics and Regularities of $\mathrm{Sb}$ and As from Antimony Mining Waste Rocks. Pol. J. Environ. Stud. 28, 4017, 2019.

7. ZHANG Y., REN B., HURSTHOUSE A., DENG R., HOU B., Hou. Study on the Migration Rules of Sb in Antimony Ore Soil Based on HYDRUS-1D. Pol. J. Environ. Stud. 28, 965, 2019.

8. JIANG F., REN B., HURSTHOUSE A., ZHOU Y. Race Metal Pollution in Topsoil Surrounding the Xiangtan Manganese Mine Area (South-Central China): Source Identification, Spatial Distribution and Assessment of Potential Ecological Risks. Int. J. Environ. Res. Public Health. 2018.

9. JIANG F., REN B., HURSTHOUSE A., DENG R. WANG Z. Distribution, source identification, and ecologicalhealth risks of potentially toxic elements (PTEs) in soil of thallium mine area (southwestern Guizhou, China). Environ. Sci. Pollut. Res. 26 (16) 16556, 2019.

10. MEI G., WU Z. Study on Social Risk Evaluation Index System for Tailings Pond Dam-Break Based on the Vulnerability Theory. Adv. Mater. Res. 594-597, 23012308, 2012.
11. PALAPA T.M., MARAMIS A.A. Heavy metals in water of stream near an amalgamation tailing ponds in TalawaanTatelu gold mining, north sulawesi, Indonesia. Procedia Chem. 14, 428, 2015.

12. REN B., ZHOU Y., MA H., DENG R., ZHANG P. Sb release characteristics of the solid waste produced in antimony mining smelting process. J. Mater. Cycles Waste Manage. 20 (1) 193, 2018.

13. ZHANG Y., REN B., HURSTHOUSE A., DENG R., HOU B. An Improved SWAT for Predicting Manganese Pollution Load at the Soil-Water Interface in a Manganese Mine Area. Pol. J. Environ. Stud. 27, 2357, 2018.

14. ZHOU Y., REN B., HURSTHOUSE A., ZHOU S. Antimony Ore Tailings: Heavy Metals, Chemical Speciation, and Leaching Characteristics. Pol. J. Environ. Stud. 28, 485-495, 2018.

15. LUMBroso D., MCELROY C., GOFF C., COLlell M.R., PETKOVSEK G., WETTON M. The potential to reduce the risks posed by tailings dams using satellitebased information. Int. J. Disaster Risk Reduc. 38, 101209, 2019.

16. QI C., FOURIE A., CHEN Q., TANG X., ZHANG Q., GAO R. Data-driven modelling of the flocculation process on mineral processing tailings treatment. J. Cleaner Prod. 196, 505, 2018.

17. HE X., ZHENG C., SUI X., JING Q., WU X., WANG J., SI W., ZHANG X. Biological damage to Sprague-Dawley rats by excessive anions contaminated groundwater from rare earth metals tailings pond seepage. J. Cleaner Prod. 185, 523, 2018.

18. LI X., LI D., XU Y., FENG X. A DFN based 3D numerical approach for modeling coupled groundwater flow and solute transport in fractured rock mass. Int. J. Heat Mass Transfer. 149, 119179, 2020.

19. WU L.Z., ZHU S.R., PENG J. Application of the Chebyshev spectral method to the simulation of groundwater flow and rainfall-induced landslides. Appl. Math. Model. 80, 408, 2020.

20. MEI G.D., WU Z.Z. Research on the dam-break hazard vulnerability assessment index system and methods of tailings pond. Appl. Mech. Mater. 204-208, 3450-3456, 2012.

21. KHADRI S.F.R., PANDE C. Ground water flow modeling for calibrating steady state using MODFLOW software: a case study of Mahesh River basin, India. Model. Earth Syst. Environ. 2 (1), 39. 2016.

22. XUE S., LIU Y., LIU S., LI W., WU Y., PEI Y. Numerical simulation for groundwater distribution after mining in Zhuanlongwan mining area based on visual MODFLOW. Environ. Earth Sci. 77 (11), 400, 2018.

23. WANG Y., QIANG Y., YANG H. Numerical simulation of groundwater pollution in a tailing pond based on Visual MODFLOW. J. Water Resour. Water Eng. 26 (05), 93, 2015.

24. PODLASEK A., BUJAKOWSKI F., KODA E. The spread of nitrogen compounds in an active groundwater exchange zone within a valuable natural ecosystem. Ecol. Eng. 146, 105746, 2020.

25. SINGH R., CHAKMA S., BIRKE V. Long-Term Performance Evaluation of Permeable Reactive Barrier for Groundwater Remediation Using Visual MODFLOW. Environ. Processes Manage. 91, 311, 2020.

26. REN B., CHEN Y., ZHU G., WANG Z., ZHENG X. Spatial variability and distribution of the metals in surface runoff in a nonferrous metal mine. J. Anal. Methods Chem. 2016, 1, 2016. 
27. WANG S., SHAO J., SONG X., ZHANG Y., HUO Z., ZHOU X. Application of MODFLOW and geographic information system to groundwater flow simulation in North China Plain, China. Environ. Geol. 55 (7), 1449, 2008.

28. LACHAAL F., MLAYAH A., BÉDIR M., TARHOUNI J., LEDUC C. Implementation of a 3-D groundwater flow model in a semi-arid region using MODFLOW and GIS tools: The Zéramdine-Béni Hassen Miocene aquifer system (east-central Tunisia). Comput. Geosci. 48, 187, 2012.

29. SINGH R., CHAKMA S., BIRKE V. Numerical modelling and performance evaluation of multi-permeable reactive barrier system for aquifer remediation susceptible to chloride contamination. Groundwater Sustainable Dev. 10, 100317, 2020.

30. WU D. Regional hydrogeological conditions of Xiangtan Manganese Mine, Hunan. J. Cent. South Univ. (Nat. Sci. Ed.). 01 (01), 31, 1958.
31. BENHACHMIL M.K., OUAZAR D., NAJI AHMED., CHENG ALEXANDER Optimal Management in Saltwater-Intruded Coastal Aquifers By Simple Genetic Algorithm. First International Conference on Saltwater Intrusion and Coastal Aquifers - Monitoring, Modeling, and Management. Essaouira, Morocco, 2001.

32. BAI X., SONG K., LIU J., MOHAMED A.K., MOU C., LIU D. Health Risk Assessment of Groundwater Contaminated by Oil Pollutants Based on Numerical Modeling. Int. J. Environ. Res. Public Health. 16, 3245, 2019.

33. HE Y., LI B., ZHANG K., LI Z., CHEN Y., YE W. Experimental and numerical study on heavy metal contaminant migration and retention behavior of engineered barrier in tailings pond. Environ. Pollut. 252, 1010, 2019. 